\title{
The effect of Islam on the design of Iranian gardens
}

\author{
B. Beizaeijouybari \& B. S. Gungor \\ Faculty of Architecture and Design, Ozyegin University, Turkey
}

\begin{abstract}
Iranians' interest on gardens goes back a long way. The concept of the Persian architectural garden, with its finesse aesthetic aspects and landscape settings, has been one of the significant cultural elements in shaping the world for centuries. However, prior to the Islamic era in Iran, Iranian gardens were mostly influenced by the Egyptians' gardening techniques and concepts which have had an added value to revitalizing the gardening geometry while further beautifying the structure of gardens in Iran. During the post-Islamic period, pleasant gardens, streams, plantations and flowers such as clove gillyflowers or roses were among the top cornerstones of Iranian culture. Water had always maintained its importance in Iranian gardens during the periods both before and after Islam. The geometrical size and shape of the gardens were more important before the Islamic era, while other parameters and factors such as the sacred numbers in the Holy Quran, water, the privacy, the trees and fruits gained more importance during the Islamic period.

Even the natural climate does not help to provide enough water and greenery at the Iranian gardens because of severe drought and hot climatic conditions in the region. The Islamic values helped in fostering the creation of four water slotted gardens in accordance with the symbols of Islam.

In this paper, a comparative study is conducted on different designs of Iranian historical gardens and Iranian gardens which are built both before and after Islam. In addition, an analysis of the changes in the major building blocks used in the design of gardens such as water, type of trees, flower elements... was done based on the Islamic perspective.

Keywords: Iranian garden, Eden, Islam.
\end{abstract}




\section{Introduction}

The evolvement of Persian gardens had started for over a millennium before Islam entered Iran and they have always portrayed the heavenly architectural gardening structure [1]. During the Islamic era, the reflection of spirituality on the people's daily life helped to create even better sceneries. The concept of an earthly paradise was the main idea behind the design of Persian gardens. As the word expresses, such gardens would have been enclosed. The garden's purpose was, and is, to provide a place for perfect relaxation and leisure such as meetings with friends, thus the ultimate reason to build a paradise on Earth. The tradition and style of Persian gardens has influenced the design of gardens from Spain to India and beyond. The Persian garden styles followed the concept of gardens from Egypt. Creating microclimatic effects, high walled structures, shady trees, streams, fountains and pools were the factors which make the Persian garden a paradise on earth. The Persian gardens are planted with different types of fruit, flower trees, shrubs, shady plants and etc. Islamic cultural values have impacted the architectural and geometrical structures of Iranian gardens, houses and even cities. The irrigation canals are also built in the gardens. The canals were built and positioned straight in order to provide water to the plants which were also planted straight along the canals. The Persian garden style spread eastwards to India and westwards via Spain with the spread of Islam and by the Romans.

\section{Phases of Iranian gardens from past to present}

Iranian gardens started at the time of Achaemenian Empire (6th century BC) in Shiraz city. The famous garden at that time was Royal Pasargad Garden. "Before the birth of Islam, gardens had been affected by geographical conditions. They were influenced by tradition, ritual, and cultural background of the people" [26]. It portrays the four sacred elements in gardening before Islam, and they are water, fire, air and soil; from the beginning of the days of the Sassanid's (224641 A.D) and onwards. As a result, when we observe ancient gardens in Iran, or in the territories which were under Iranian influence, the artificially built microclimatic conditions were all the same almost throughout the entire Islamic empire and Persia. They had a peculiar model for the microclimatic effect in the garden.

Some Iranians known as "Parsians" migrated to India after the Islamic era. They might be the first group of Iranians to import the idea of Persian garden to India which maintains still its importance in the design of gardens.

Now just some limited examples remained of those gardens that reflect the design characteristics of Persian or traditional Iranian gardens. One of the popular Iranian gardens was Kalat (place of sun) Naderi. It was for the Afsharieh Empire (1151 AD) and before Islam. It was just a garden with big pavilion and one small river in the center. 


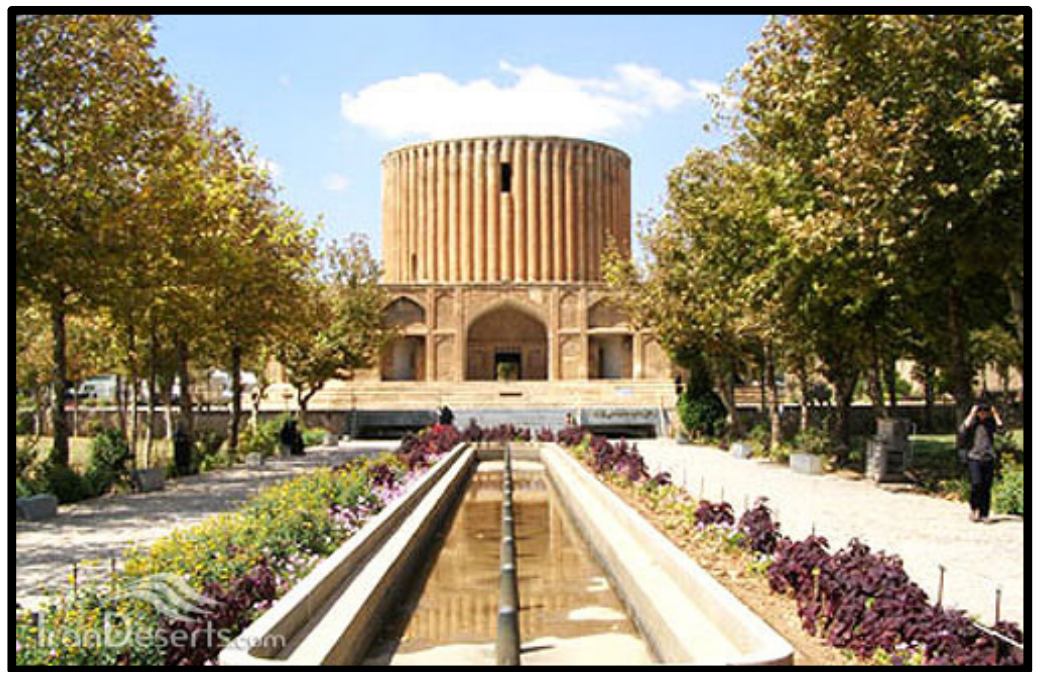

Figure 1: Kalat Naderi Garden.

\subsection{Iranian gardens before Islam}

Before the Islamic era, gardens were both affected by geographical conditions, traditions, and cultural backgrounds. Religion was always influential in Iran. In Zardtoshtian religion (first religion of Iran), we had Amrdad. He was the goddess of plants in Iranian Myths. It shows the Iranian behavior, manner against plants and gardens with those traditional mythical stories.

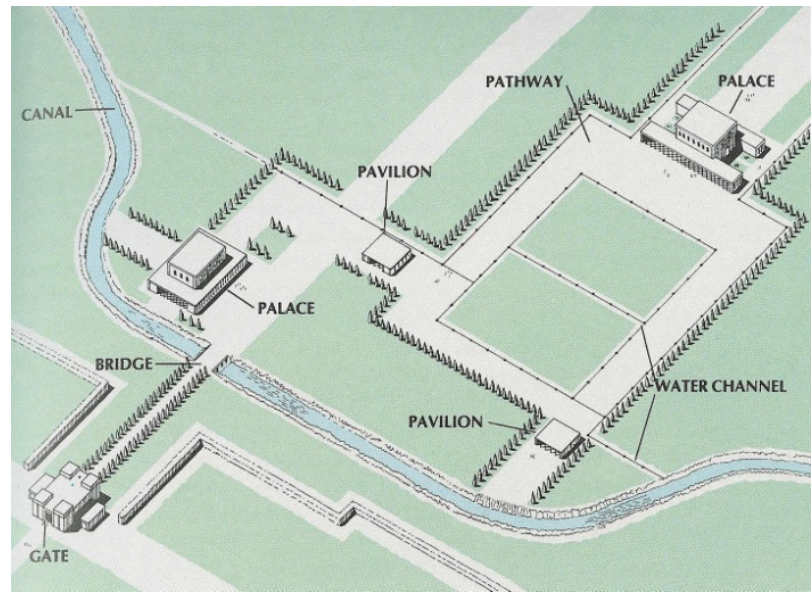

Figure 2: Achaemenid Gardens. 


\subsection{Iranian gardens after Islam}

"One day shalt thou see the believing men and the believing women- how their light runs forward before them and by their right hands: (their greeting will be): good news for you this day! Gardens (eden) beneath which flow rivers! To dwell therein for aye! This is indeed the highest achievement" (Quran Chapter AlHadid (57), Verse No: 12 Iron). As in this Verse of The Quran, there are many similar verses that make reference to the paradise gardens. In the mid-seventh century the Muslim armies led by the Umayyad (661-750), the first hereditary dynasty of Islam conquered the lands, that are known today as Syria, Jordan, Israel, Palestine, Lebanon, Iraq and most of Iran. After that burgeoning population of Muslim began to converts city dwellers, nomadic people, and settled farmers. By the early 8th century, this territory extended from Syria westward across northern Africa to Morocco and the Iberian Peninsula, and eastward through Iran to Central Asia" (Fairchild cited in [14]).

After the emergence of Islam, people found new explanation of Eden (Behesht) and got new idea for gardens. After Islam, Iranian gardens evolved with the Islamic idea. In Islamic idea, garden was the symbol of paradise. According to Quran Paradise or Behesht is a perfect place for being in peace. There are a lot of boon, streams, water, flowers, fruits, shadow and everything to be in peace. In this definition, gardens should be a perfect place that there is no drought and water scarcity. It was very hard for Iran to create a garden like that because Iran has hot and dry climatic conditions. According to this belief, wealth, enough water, trees, fruits, shadow were important things for gardens. "Eat and drink at ease for that which you have sent forth (good deeds) in days past!" (Quran Chapter Hâkka (69), Verse No: 24 Iron) without scrutinizing the meaning behind this verse, if we just get the tangible meaning of it, it is very difficult to create those kinds of gardens on that location. In any way, Iranians forced themselves to create a garden similar to those that identified in the Quran by building water slots in the garden to create microclimatic conditions and cooling effect [15].

After Islam, some sacred symbols started to be used in the design of gardens. Those will be explained below:

\subsubsection{Numbers}

There are a lot of myths occurring as shape in Islam. One of them is the numbers. In Quran some numbers are sacred as four, seven, five, six, eight, forty and twelve and so on. Four represents the four level of Quran, six represents behind veracity level. Eight represents paradise. After Islam, these sacred numbers were used in both architectural and environmental designs to symbolize the true meaning of the numbers.

Kakh 8 Behesht in Isfehan whereby the plan is divided into 8 chambers surrounding a central room. 4 bagh (4 gardens). 40 columns garden in Isfahan. The Chahrbagh (or 4bagh Avenue) in Isfahan, Iran, built by Shah Abbas the Great in 1596, and the garden of the Taj Mahalin India are the most famous examples of this style. 


\subsubsection{Water material}

Iranian artists' interpretation of the garden as a holy place, tries to collect holly symbols. Since water symbolizes cleanliness and purity in Islam, it has an important role [6]. The most important thing to enliven the garden was bringing water from distant areas to the garden. It was previously mentioned that lack of water was a common problem in Iran but the problem solved by digging wells and aqueducts. There is an explanation about that the water is the meaning of life in Quran as; "Have not the unbelievers ever considered that the skies and the earth were once one mass, then We split them asunder? And we have created every living thing from water. Will they still not believe? (Quran Chapter AlAnbiyaa (21) Verse No: 30, Malik). Subterranean water was lead to the streams and regular table, by passing the main vessel flow into thought side streams. This method of irrigation (watering) influenced the garden design, in other words, garden design was made thought divining the flowing water and creating of major and minor axis.

After Islam, according to Quran, most gardens have four rivers. It is symbol of fore four rivers in a paradise. In Quran Chapter Muhammed (47) verse 15: there are four rivers in paradise.

First River of water: its taste and smell do not change. It is symbol of life; it is the first level of Islam, providing cleanliness.

Second River of wine: it is the symbol of happiness and life. Here, it refers to Jesus level. Third level of Islam

Third River of milk: it represents love it is the symbol of growth; get the knowledge behind the verses. Grow with knowledge.

Fourth River of honey: it is delicious and sweet. Fourth level of Islam [21].

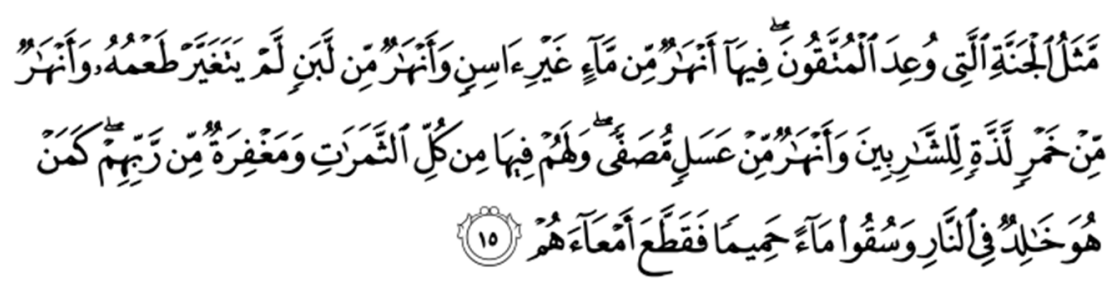

Figure 3: Quran Chapter Muhammed [21].

Sahih International: is the description of Paradise, which the righteous are promised, wherein are rivers of water unaltered, rivers of milk the taste of which never changes, rivers of wine delicious to those who drink, and rivers of purified honey, in which they will have from all [kinds of] fruits and forgiveness from their Lord, like [that of] those who abide eternally in the Fire and are given to drink scalding water that will sever their intestines?

Pickthall: a similitude of the Garden which those who keep their duty (to Allah) are promised: Therein are rivers of water unpolluted, and rivers of milk whereof the flavor changeth not, and rivers of wine delicious to the drinkers, and rivers of clear-run honey; therein for them is every kind of fruit, with pardon 
from their Lord. (Are those who enjoy all this) like those who are immortal in the Fire and are given boiling water to drink so that it teareth their bowels?

Yusuf Ali: (Here is) a Parable of the Garden which the righteous are promised: in it are rivers of water incorruptible; rivers of milk of which the taste never changes; rivers of wine, a joy to those who drink; and rivers of honey pure and clear. In it there are for them all kinds of fruits; and Grace from their Lord. (Can those in such Bliss) be compared to such as shall dwell forever in the Fire, and be given, to drink, boiling water, so that it cuts up their bowels (to pieces)?

Islamic Iranian and Islamic gardens have 4 parts with 4 rivers but just a schematic of Fin garden in Kashan can be considered as an example for this kind of gardens.

\subsubsection{Privacy between garden and pavilion}

There are rules accepted by the populations of Islam, actually those rules change according to the cognizance. In Iran some religious rules apply both to men and woman. Those rules mostly include privacy. Since Royal family lived in pavilion in those gardens, Iranian added more privacy in building. On the other hand, there were extra and separated pools in pavilion for woman after Islam.

\subsubsection{Trees and fruit}

After Islam, Iranian people used trees and flowers according to the Quran and Islamic tradition that explained paradise. Praise be to Allaah.

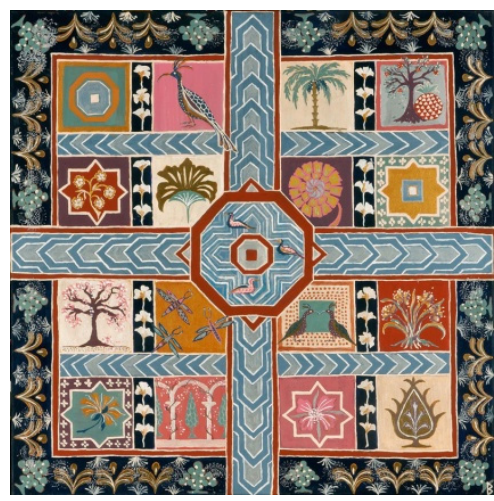

Figure 4: Iranian garden painting, Berit.

The date palm tree: This is a good tree to which Allaah liked the word of Towheed when it is established in the sincere heart, where it bears fruits of good deeds that strengthen eemaan (faith).

Allaah says (interpretation of the meaning): "See you not how Allaah sets forth a parable? - A goodly word is as a goodly tree, whose root is firmly fixed, and its branches (reach) to the sky (i.e., very high)." (Quran Chapter Ibraaheem (14) Verse: 24). 


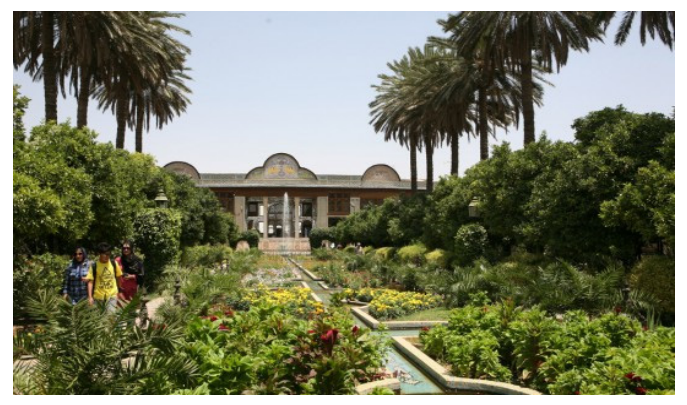

Figure 5: The Bagh-e Narajestan, ISNA.

This is the tree to which Allaah likes the believer because it is good in all aspects, it is lasting and it offers different kinds of benefit. Ibn 'Umar reported: "The Prophet (peace and blessings of Allaah be upon him) said: 'There is a kind of tree whose leaves do not fall and it is like the Muslim. Tell me what it is.' The people mentioned different kinds of desert trees ... and I said to myself, 'It is the date palm tree,' but I felt too shy to speak up. Then the people said, 'Tell us what it is, O Messenger of Allaah.' He said: 'It is the date palm tree."' (al-Bukhaari, 60).

Iranians used the palm tree (Arecaceae, Phoenix dactylifera is very important in Islam) a lot. Because it is a traditional tree and it is compatible with Iranian climatic conditions as well.

The blessed olive tree (Olea europaea): The purity of which Allaah set forth as a parable. (فيى سِيْرِ مَخْضُوٍِ (22].

Lotus tree: In fact, the loudest descriptive that our earthly Paradise tree in the form of words is possible, because the "Lotus" as some tree with height there of sometimes up to forty meters, and lives two thousand years. This tree's shadow is very heavy and delicate.

Tuba trees: The most famous Paradise tree is the "Tuba tree" and only once in the Quran and in verse 29 of Sura Raad, the term used Tuba tree is not of course meant by this verse, but the Islamic tradition told "Tooba is a tree in Paradise, it used trunk in the house of the prophet of Allah Muhammad and at home, every believer is a branch of it."

Pomegranate trees: There is another part in Quran that where is fruit, the date-palm and pomegranate (Quran Chapter Alrahman (68)).

Banana tree: among tall trees with flowers (or fruits) piled one above another, in shade long-extended, by water flowing constantly, and fruit in abundance (Quran Chapter Vaqeh (56)).

\section{Conclusion}

We can see that minor effects of Islam on some part of Iranian gardens (as presented in figure 2) since Iranian historic garden styles (before Islam) were similar to those garden styles that are mentioned in the Quran. There were 4 rivers used in historic garden design. Four gardens, sprats pool for woman. 
Iranian gardens are beneficiary of Islamic style. Islam supported garden designs in Iran that by some gardening definitions as trees, flowers and streams. People enjoy Iranian historical gardens on summer, when it reached $40^{\circ} \mathrm{C}$, people also seat in shadow under the tall trees, near rivers and ate fresh fruits in desert part of Iran. This can be referred to as the concept of the paradise defined in their mind.

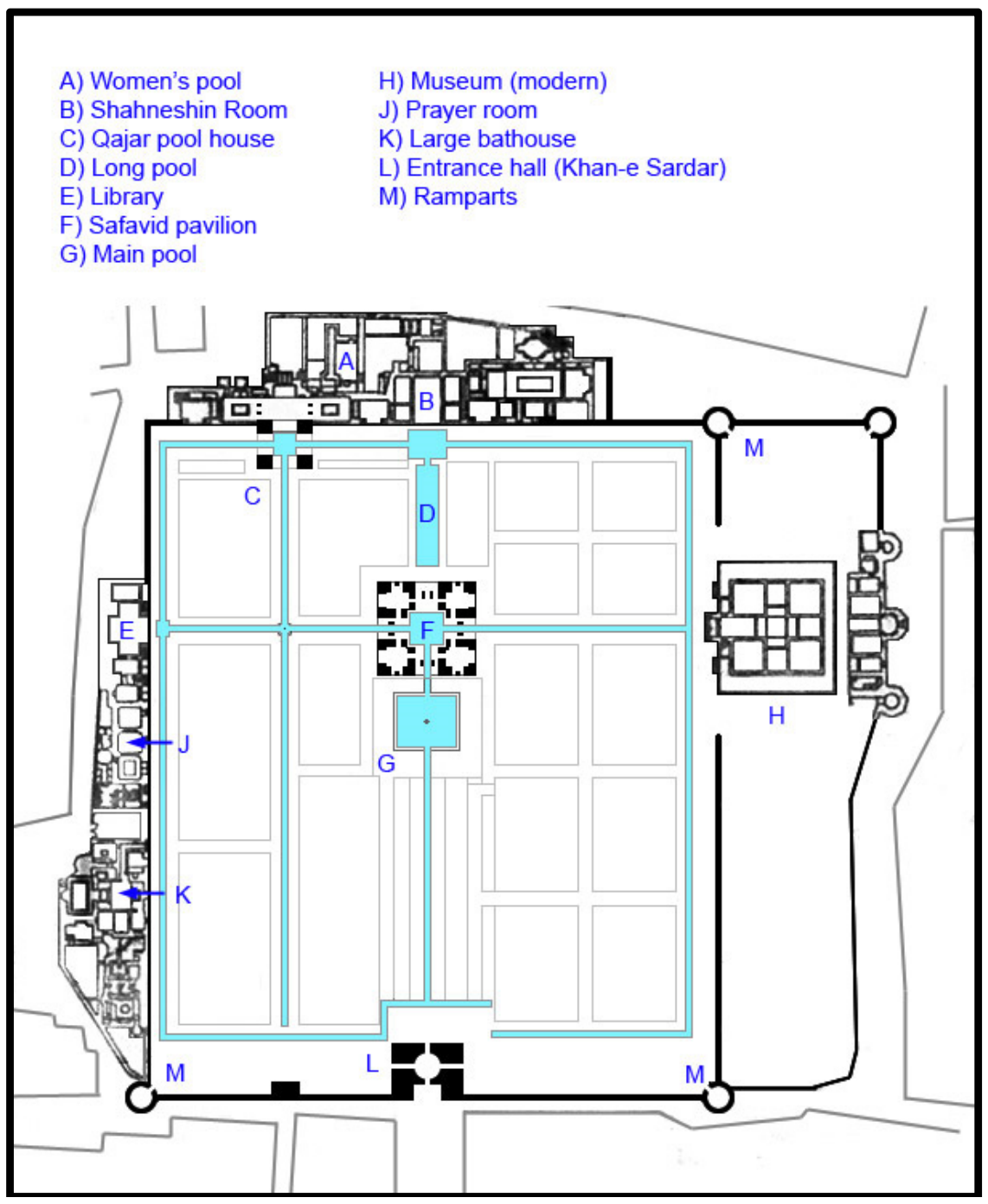

Figure 6: Fin garden.

By summarizing the change of Iranian gardens before and after Islam, then we can clearly say that the size and the geometrical shape of the garden was sent back in the order of importance; instead 4 streams, trees, fruits, privacy came 
forth. Microclimatic effects created by building water slots even in the drought by digging wells and aqueducts were the priority of the gardeners. This was the most refreshing effect on people especially in summertime because of the cooling effect.

\section{References}

[1] Curatola, G., \& Scarcia, G. (2007). The art and architecture of Persia. Abbeville Press.

[2] Hattstein, M., \& Delius, P. (1965) Islam: Art and Architecture. George Braziller, Inc.

[3] Hillenbrand, R. (1994). Islamic architecture: Form, function, and meaning. Columbia University Press.

[4] Crane, H. G. (1979). Architecture of the Islamic World, Its History and Social Meaning George Michell. Journal of the Society of Architectural Historians, 38(4), 385-386.

[5] O'Kane, B. (2016). 6 Arthur Upham Pope and the Study of Persian Islamic Architecture. In Arthur Upham Pope and A New Survey of Persian Art, Brill, 110-124.

[6] Stierlin, H. Islam: From Baghdad to Cordoba Taschen GmbH, 2009.

[7] Saba, M., Iranian Gardens and Garden Palaces, Scientific and Cultural Publication, 2006.

[8] AriyanPour, A., Research in Iranian Gardens and Shiraz Cultural Gardens, Yasavovli Publication, 2006.

[9] Naeima, Gh., Iranien Gardens, Payam Publication, 2006.

[10] AriyanPour, A., Research in Iranian Gardens and Shiraz Cultural Gardens, Yasavovli Publication, 2006.

[11] Pirnia, K., Iranian Garden, Journal of Abadi, Vol. 4, No. 15, pp. 6-10, 1994.

[12] Moayyed, A., Garden City (Iranian Idea or European Idea), Journal of Art and Architecture, Vol. 4, No. 43, pp. 37-40, 1977.

[13] Saba, M., Iranian Gardens and Garden Palaces, Scientific and Cultural Publication. 2006.

[14] N, Ansari, Faculty of Landscape Studies, LA901, 2011.

[15] Ansari, Mojtaba 1999, PhD Thesis in Architecture, Tehran University, Tehran.

[16] Ansari, Mojtaba "Persian Garden as Eden allegory, emphasizing the value of Persian Garden during Safavid dynasty," (29) 3948, 2007.

[17] G. Bazin, Paradeisos: The Art of the Garden, Boston, Toronto, and London, pp. 12-13, 1990.

[18] M. Boyce, Zoroastrians: Their Religious Beliefs and Practices, Boston, and Melbourne, p. 77, 1979.

[19] Muhammad Nabi, Quran, Al-Anbiyaa, Makkeh Chapter 21, Verse No: 30, Malik.

[20] Muhammad Nabi, Quran, Ar-Ra'd, Makkeh, Chapter 13, Verse 29, Yusuf. 
106 Islamic Heritage Architecture and Art

[21] Muhammad Nabi, Quran, Muhammed, Makkeh, Chapter 47, verse 15, Asad.

[22] Muhammad Nabi,Quran, sūrat l- Nabi, Makkeh, Chapter 59,verse 21.

[23] D. N. Wilber, Persian Gardens and Garden Pavilions, Tokyo, 1962.

[24] Shazde Mahan Garden Kerman. (n.d.). Retrieved April 21, 2016, from https:/www.360cities.net/image/shazde-mahan-garden-kerman-iran-2

[25] A walled paradise: A history of Iranian gardening. (2014). Retrieved April 21, 2016, from http://www.theguardian.com/world/iran-blog/2014/oct/30/ iran-walled-garden-paradise

[26] Shazde Mahan Garden Kerman. (n.d.). Retrieved April 21, 2016, from https://www.360cities.net/image/shazde-mahan-garden-kerman-iran-2

[27] Farrokh, K. (n.d.). Achaemenid Gardens. Retrieved April 23, 2016, from http://kavehfarrokh.com/ 